\title{
Podstawowe problemy językoznawstwa antropologicznego
}

\author{
Piotr P. Chruszczewski \\ Uniwersytet Wrocławski \\ piotrchruszczewski@interia.pl
}

\section{(Zamiast) Streszczenia}

“Wysitek autora został skupiony na połaczeniu zgłębiania języka ze zgłębianiem innych gałęzi antropologii, bowiem język jest najlepiej rozumiany gdy nawyki, obyczaje, instytucje, filozofia - esencja myśli urzeczywistnionej w języku - sa najlepiej poznane. Badacz języka powinien zajmować się ludźmi, którzy mówia tym językiem; to właśnie było celem napisania tej książki [pracy-P.C.], zawierajacej wiele odniesień do innych gatęzi antropologii”. Powell ([1877] 1880: vi)

Słowa kluczowe: językoznawstwo antropologiczne, lingwistyka kontaktu, socjolingwistyka, pragmatyka, wzory kultury, praktyki dyskursywne

(In lieu of) An Abstract

Basic Issues of Anthropological Linguistics

"It has been the effort of the author to connect the study of language with the study of other branches of anthropology, for a language is best understood when the habits, customs, institutions, philosophy - the subject-matter of thought embodied in the language - are best known. The student of language should be a student of the people who speak the language; and to this end the book [paper-P.C.] has been prepared, with many hints and suggestions relating to other branches of anthropology." Powell ([1877] 1880: vi)

Keywords: Anthropological Linguistics, Contact Linguistics, Sociolinguistics, Pragmatics, cultural patterns, discursive practices 
Językoznawstwo antropologiczne stało się w ostatnim czasie bardzo obszerną dyscypliną, obejmującą swoim zasięgiem kilka dużych, w zasadzie już samodzielnych i wyodrębnionych dyscyplin takich jak np. językoznawstwo kontaktu, językoznawstwo terenowe, socjolingwistyka, czy pragmalingwistyka (zob. też Klein 2006). Językoznawstwo antropologiczne ma wiele obszarów wspólnych i zbieżnych przedmiotów badań z wieloma innymi kierunkami badań prowadzonymi w zakresie językoznawstwa Można przyjąć, że podstawowym założeniem językoznawstwa antropologicznego jest pogłębianie i systematyzowanie wiedzy na temat, przede wszystkim komunikacyjnych zachowań człowieka (podobnie jak studiów nad komunikacją, ang. communication studies); jego biologicznie ukonstytuowanych możliwości i potrzeb komunikacji werbalnej (podobnie jak neurolingwistyka i psycholingwistyka); jakości i intensywności typów kontaktów człowieka z innymi ludźmi, prowadzących do modyfikowania swojego środowiska życia przez komunikację werbalną (jak socjolingwistyka); czy też badanie relacji miedzy człowiekiem a kulturą, w której przychodzi mu żyć, i jaką sam formuje przez swoje zachowania symboliczne (jak semiotyka lingwistyczna), komunikowane często w ściśle określonych sytuacjach nadawczo-odbiorczych (jak pragmalingwistyka).

Językoznawstwo antropologiczne posługuje się w badaniach narzędziami i metodami językoznawczymi, ale też nie stroni od metod badawczych wykorzystywanych w antropologii kulturowej, etnografii a nawet w archeologii. Wczesny rozwój językoznawstwa antropologicznego charakteryzował się dużym naciskiem położonym (przynajmniej w teorii) na komplementarność: antropologii kulturowej, fizycznej (tak naprawdę biologicznej), archeologii i językoznawstwa, co było szczególnie ważne przy interpretacji badanej kultury (szczególnie często badano różne kultury Indian amerykańskich). Wiązało się to z poznaniem i zrozumieniem funkcjonowania języka w jego szerszym, kulturowym aspekcie. Badacze ze szkoły Franza Boasa często starali się nie tylko poznać opisywaną przez siebie kulturę, ale też - często przede wszystkim język przez współuczestnictwo w kulturze, którą dokumentowali, i przez pogłębioną obserwację uczestniczącą (ang. participant observation). Opisana tutaj metoda prowadzenia badań w terenie może być określana jako językoznawstwo terenowe (ang. field linguistics) (zob. np. Bowern 2008). Między innymi posługiwanie się właśnie tą metodą pozwoliło zauważyć, że nie ma języków gorszych ani lepszych, a każdy język należy badać w odniesieniu do jego własnej kultury i jego użytkowników. 
Jedną z wersji powyższego stwierdzenia nazwano hipotezą Sapira-Whorfa, która w swojej radykalnej formie ma bardzo niewielu zwolenników, gdyż znaczyłoby to tyle, co bezpośrednie stwierdzenie, że język jakiego się używa, kieruje sposobem postrzegania świata użytkownika tego języka. Hipoteza Sapira-Whorfa (znana też jako zasada relatywizmu językowego), nie przyjęła się w swojej radykalnej postaci, i obecnie już niemal nikt nie ma wątpliwości, że ludzki umysł nie zachowuje się wedle takiego prostego modelu budując znaczenia w komunikacji. Mimo to przyjąć trzeba, że mniej radykalna wersja tej hipotezy ma ze wszech miar rację bytu, ponieważ jej prawdziwość, potwierdziły materiały badawcze z wielu języków: łatwiej jest zapamiętywać i określać obiekty i procesy mające dokładną nazwę w języku, którym na co dzień posługuje się nasz respondent (zob. Whorf 1956; Lucy 1992).

Hipoteza Sapira-Whorfa, nawet w swojej radykalniejszej postaci, wydawała się jednak możliwa do przyjęcia jeszcze w latach 50. minionego wieku, czyli do początku rozwoju nauk zorientowanych kognitywistycznie. Nowe badania sprawiły, że językowa złożoność i potencjał generowania znaczeń muszą opierać się na dużo głębszej kognitywnej i gatunkowo dziedziczonej podstawie, niż tylko na kulturowych wzorach językowego zachowania wypracowanych przez ludzi w różnych częściach świata i w różnych sytuacjach. W konsekwencji rewolucja kognitywna postulowała, że zmienność kulturowa w języku jest w gruncie rzeczy tylko powierzchniowa w zestawieniu $\mathrm{z}$ kognitywnymi uniwersaliami (zob. Levinson 1997 2003; Wierzbicka 1996; Gumperz i Levinson 1996). Uniwersalizm kognitywistyczny w swojej skrajnie radykalnej wersji zaproponowanej przez Jerrego A. Fodora $(1975,1983)$ zakłada, że wszystkie możliwe koncepty człowieka pochodzą z wrodzonego ,języka myśli” (ang. language of thought) czy też Mentalese - języka, w którym myślimy (Pinker 1994: 55-82; Carruthers 1996), a wszystkie koncepty znaczeniowe w językach naturalnych są jedynie projekcjami konceptów z repertuaru kognitywnych uniwersaliów. Przy takim pojmowaniu rzeczy, akwizycja pierwszego języka sprowadzałaby się tylko do znalezienia odpowiedniej kulturowo-lokalnej korelacji między miejscowymi realizacjami (dźwiękowymi) a znaczeniami uniwersalnymi (Pinker 1994). Wydawać by się mogło, że - jak to ujmuje Stephen Levinson - doktryna kognitywnego uniwersalizmu i założenia radykalnej wersji hipotezy Sapira-Whorfa stoją wobec siebie w wyraźnej opozycji. Relacje tej opozycji (Levinson [1997] 2003: 460) można przedstawić w następujący sposób: 

A. Różne języki używają różnych parametrów semantycznych.
B. Kategorie semantyczne umożliwiają użycie różnych konceptów.
C. Użytkownicy różnych języków używają różnych konceptów.

- $\quad$ Uniwersalizm kognitywistyczny (propozycja w oparciu o prace zamieszczone w zbiorze redagowanym przez Gumperza i Levinsona z 1996 roku)

A. Wszystkie języki używają tych samych parametrów semantycznych.

B. Koncepty uniwersalne determinują kategorie semantyczne.

C. Użytkownicy różnych języków używają tych samych konceptów.

Co ciekawe, żadna z powyższych hipotez nie sprawdza się w swojej radykalnej wersji, natomiast połączenie elementów obu doktryn jest jak najbardziej do zaakceptowania jako rozsądna i produktywna perspektywa badawcza. Według Levinsona ([1997] 2003: 460) zdecydowana większość zwolenników uniwersalizmu kognitywistycznego przyjmuje, że koncepty językowe są zbudowane z mniejszych elementów, które dodają się, tworzą ostateczne znaczenie. Innymi słowy, większość badaczy zgadza się z pojęciem dekompozycji leksykalnej (ang. lexical decomposition), które opisuje proces tworzenia znaczeń. Polega on na tym, że złożone koncepty, takie jak np. „ojciec”, są złożone z konceptów podstawowych, takich jak w tym wypadku „mężczyzna”, „rodzic”, „człowiek”. Na podstawie powyższych przemyśleń Levinson ([1997] 2003: 460) proponuje następującą zmodyfikowaną hipotezę neo-whorfiańską:

A. Możliwe jest, że wszystkie języki używają tych samych podstawowych konceptów semantycznych, ale różnią się w sposobie komponowania tych konceptów w celu uzyskania złożonych konceptów leksykalnych czy gramatycznych.

B. Uniwersalne koncepty są złożone w kulturowo-molekularne kombinacje, odpowiadające znaczeniom słów, co może odgrywać pewną rolę w myśleniu.

C. Użytkowników różnych języków łączy głębsza jedność psychiczna (ang. psychic unity), ale posiadają oni cały repertuar różnych konceptów wykorzystywanych w swoich procesach myślenia.

Trudno znaleźć bezpośrednie i bezapelacyjnie przekonujące dowody, że jest właśnie tak, jak zakłada Levinson. Podobnie też trudno byłoby udowodnić, że dziecko rodzi się z wrodzonym „mechanizmem” (ang. faculty) umożliwiającym mu stosunkowo szybkie 
opanowanie skomplikowanego symbolicznego kodu, jakim jest język. Za oczywiste należy uznać i to, że różne języki mają specyficzne dla siebie środki wyrazu, które są na pewno nieobecne w ,języku myśli” (Levinson 1997), i które dopiero musimy nabyć i przyswoić w kulturowym procesie uczenia się języka.

Jeden z wrocławskich badaczy paradygmatów językoznawstwa kulturowego Janusz Anusiewicz (1994: 10-11) - zaproponował trzy główne dyscypliny związane z tą dziedziną badań: lingwistykę kulturową; lingwistykę antropologiczną (etnolingwistykę) i antropologię lingwistyczną, zaznaczając, że pojęcia te są bardzo często używane zamiennie, a praktyka uprawiania tych dyscyplin nie jest jeszcze w Polsce specjalnie rozbudowana i zweryfikowanie tych pojęć może nastąpić jedynie w praktyce badawczej. Anusiewicz (ibid.) podejmuje próbę rozgraniczenia zakresów badawczych wskazanych przez siebie pojęć w następujący sposób:

A) Lingwistyka kulturowa bada związki między językiem a kulturą, a jej podstawowym zadaniem jest studium relacji: język - kultura - człowiek (społeczeństwo) - rzeczywistość. „Język jest tu traktowany jako jej warunek wstępny, implikator, składnik, rezerwuar, 'pas transmisyjny' oraz interpretator i interpretant zawierający najistotniejsze treści kultury" (Anusiewicz 1994: 10).

B) Lingwistyka antropologiczna (etnolingwistyka) bada związki i zależności między językiem a człowiekiem (społeczeństwem) oraz kulturą i rzeczywistością, która go otacza. „Nauka ta dąży do zrozumienia wszystkiego, co dotyczy człowieka, wszelkich spraw związanych $\mathrm{z}$ jego rozwojem jako istoty społecznej oraz zrozumienia jego aktualnych zachowań i wytworów kulturowych. Jej podstawowym zadaniem byłoby badanie czteroczłonowej relacji: język - człowiek (społeczeństwo) - rzeczywistość kultura" (ibid.).

C) Antropologia lingwistyczna bada związki między kulturą, językiem a danym społeczeństwem. „W badaniach swych wychodzi więc od kultury - nie zaś od języka i danych językowych, co jest istotną różnicą metodologiczną w porównaniu z punktem i kierunkiem wyjścia, jaki przyjmuje lingwistyka kulturowa czy lingwistyka antropologiczna" (Anusiewicz 1994: 10-11). Co ciekawe, Ben Blount podobnie jak większość autorów rozważających tę terminologiczną kwestię jest zadania, że językoznawstwo antropologiczne jest bardzo często używane wymiennie z terminem antropologia językowa, niemniej dodaje, że z historycznego punktu widzenia, jeśli chodzi o wykształcenie się tej dyscypliny z nauk humanistycznych, to trzeba mieć na uwadze, że termin językoznawstwo antropologiczne jest czasem używany do określenia studiów nad 
językami jako zjawiskami lingwistycznej natury, ale dla celów antropologicznych. Blount dodaje, że taki sposób prowadzenia badań i podejścia do samego zjawiska języka był charakterystyczny dla antropologii we wczesnych dekadach XX wieku. Pojęcie językoznawstwo antropologiczne było używane dla opisania dużo szerszego zakresu materiału niż ma to miejsce obecnie. Natomiast, jak dalej zauważa Blount, antropologiczne studium języka, lingwistycznie rzecz ujmując, jest niczym innym tylko językoznawstwem antropologicznym, wyróżniającym się spośród innych dyscyplin językoznawstwa swoją antropologiczną perspektywą badawczą i odróżnia się od antropologii lingwistycznej językoznawczą metodologią prowadzenia badań (Blount 1995: 37).

Blount proponuje też spojrzeć na tę terminologiczną różnicę z punktu widzenia historii nauki. W tym wypadku historii wydawniczej dwóch periodyków o zazębiających się zakresach badawczych. Starszym z periodyków, o których mowa, jest Anthropological Linguistics (pol. Językoznawstwo antropologiczne), zawierający głównie prace dokumentujące języki autochtoniczne Ameryki Północnej, natomiast młodsze pismo pt. Journal of Linguistic Anthropology (pol. Czasopismo antropologii lingwistycznej), jest periodykiem o szerszym zakresie, w którym zawierają się prace dotyczące bardzo wielu typów praktyk kulturowych człowieka, przejawiających się w języku, i w sumie nosi tytuł najdokładniej określający typ działalności naukowej w nim prezentowanej, tj. antropologię języka. W oparciu o współczesny stan wiedzy i badań prowadzonych w róznych ośrodkach naukowych na świecie zaproponować można następującą taksonomię:

\section{Antropologia języka:}

antropologia lingwistyczna - bada związki między kulturą, językiem a określoną społecznością mowną ${ }^{1}$;

lingwistyka kulturowa - jednym z jej założeń jest badanie relacji: język - kultura - człowiek - rzeczywistość ${ }^{2}$; (np. hipoteza Sapira-Whorfa ${ }^{3}$ );

językoznawstwo antropologiczne (główne kierunki badań):

językoznawstwo terenowe (ang. field linguistics), zajmuje się dokumentacją języków (w tym języków ginących) i praktyk językowych;

językoznawstwo typologiczne zajmuje się typologizacją języków świata;

językoznawstwo kontaktu zewnątrzspołecznego: 
kreolingwistyka - opisuje i bada procesy powstawania pidżynów, języków kreolskich i języków mieszanych, powstających i zmieniających się wraz $z$ rozwojem kontaktów społecznych;

makrosocjolingwistyka - bada i opisuje zmianę lub śmierć języka zachodzące w wyniku kontaktu większych społeczności mownych;

\section{językoznawstwo kontaktu wewnątrzspołecznego:}

mikrosocjolingwistyka - bada etnografię mówienia, akty mowy, grzeczność językową, związki języka z płcią, zmiany zachodzące w języku wewnątrz społeczności mownych;

pragmalingwistyka - zajmuje się opisem bezpośredniej sytuacji komunikowania, typów dyskursów jakimi dana społeczność mowna się posługuje; badaniem typów i stopnia rozwoju praktyk dyskursywnych danej społeczności mownej; badaniem antyjęzyka, powstającego zawsze w jakiejś określonej sytuacji komunikacyjnej, itp ${ }^{4}$.

Wedle Williama Foleya (1997: 40) można wyróżnić dwa podstawowe koncepty językoznawstwa antropologicznego, a są nimi kultura i język. Przy czym Foley od razu zauważa, że żaden $\mathrm{z}$ tych konceptów nie tworzy monolitycznego bloku wiedzy w umysłach użytkowników języka, ale raczej koncepty te stanowią „luźno ułożone domeny praktyk, przez które ludzie odgrywający role społeczne z rozmysłem nawigują w świecie” (Foley 1997: 40, tłum. - P.C.). Zaraz po tym Foley dodaje, że kultura jest „,po prostu domeną praktyk kulturowych, przez które ludzie utrzymują potrzebne im relacje społeczne” (ibid.). Z kolei praktyki językowe Foley słusznie kwalifikuje jako „podtyp kulturowych praktyk komunikacyjnych, utrzymujących więzi społeczne przez użycie znaków językowych” (ibid.). A z uwagi na to, że podtrzymują cały czas więzi społeczne, to wedle Foleya stają się typowymi emblematami różnic społecznych. Foley dodaje, że znajomość tych kulturowych praktyk komunikacyjnych jest ściśle związana z przynależnością do różnych grup społecznych.

Problemem czysto technicznym, jaki się tutaj pojawia, jest rozważenie kwestii tego, czy to znajomość kulturowych praktyk komunikacyjnych przyporządkowuje nas do odpowiednich społeczności mownych, czy też dzieje się wręcz odwrotnie, tzn. czy to 
właśnie nasza przynależność do tych czy innych społeczności mownych wyposaża nas w znajomość odpowiednich kulturowych praktyk komunikacyjnych. Foley przedstawia dość jasną definicję praktyki kulturowej i praktyki językowej. Otóż stwierdza on, co następuje: ,[] jeśli praktyki kulturowe są tymi znaczącymi praktykami, przez które ludzie pozostający w relacjach między sobą utrzymują trwające historie ustrukturowanych społecznych powiązań, wtedy wiodącymi wśród nich muszą być praktyki językowe. To co ludzie bez przerwy robią w każdej znanej społeczności, to mówienie. Praktyki językowe są najbardziej wszechobecnym sposobem, przez który ludzie podejmują decyzje i podtrzymują systemy społeczne; [praktyki językowe - przyp. P.C.] nie wyczerpują ludzkich praktyk kulturowych, ale w oczywisty sposób są wśród nich prymarne. Ludzi można krótko podsumować jako byty uspołecznione przez język" ". Stąd jasno wyprowadzić można definicję praktyki językowej, która brzmieć będzie w następujący sposób: „[praktyka językowa] (...) jest to jakakolwiek praktyka komunikacyjna, która sprzyja koordynacji działania między ludźmi w trwającym społecznie ustrukturowanym powiązaniu za pomocą zdolności przenoszenia znaczenia przez znaki wybrane z wielkiego systemu znaków i ich możliwości kombinatorycznych zwanych językiem"

Z koncepcją Foleya w dużej mierze zgodziłby się Anusiewicz, z tym zastrzeżeniem, że Anusiewicz dwch największych konceptów Foleya (tj. języka i kultury) nie nazwałby językoznawstwem antropologicznym ale raczej umieściłby je w dyscyplinie językoznawstwa kulturowego, określiwszy „najistotniejszymi zagadnieniami w badaniach lingwistyczno-kulturowych” (Anusiewicz 1994: 57), bowiem dla niego „,...) lingwistyka kulturowa stara się określić pojęcie języka, wskazać na jego najważniejsze cechy kulturowe oraz odniesienia w stosunku do kultury, której był implikatorem i podłożem, i w obrębie której ewoluował, będąc jednocześnie jej częścią składową, wykładnikiem oraz swoistym rezerwuarem" (ibid.). Mając na uwadze ten nierozerwalny związek języka z kulturą, głęboką synergię obu systemów, związek zawsze idący w parze rozwoju bądź dezintegracji, można przyjąć definicję Anusiewicza z całym dobrodziejstwem jej inwentarza, o którym sam autor pisze: „(...) język można wstępnie zdefiniować jako semiotyczny systematoid (system podsystemów), zawierający określone (tzn. zrelatywizowane do danej wspólnoty kulturowo-komunikacyjnej) ujęcie rzeczywistości pozajęzykowej oraz zobiektywizowany stosunek emocjonalnowartościujący do tejże rzeczywistości, przy czym to ujęcie i to wartościowanie jest utrwalone w poszczególnych podsystemach języka, a następnie transmitowane i 
przejmowane przez kolejne pokolenia, które owo ujęcie i wartościowanie świata zachowują bądź zmieniają, dodając do owego pierwotnego (pierwszego, podstawowego) ujęcia swoje własne, będące odbiciem aktualnego poziomu oraz stanu cywilizacji, wiedzy tejże kultury” (Anusiewicz 1994: 57-58). Zaraz Anusiewicz (1994: 58) dodaje, iż „(...) język jest raz dokonanym i ciągle dokonującym się aktem poznania w stosunku do rzeczywistości pozajęzykowej, aktem, którego rezultaty są dobudowywane i nakładane na poprzednie, zmieniając je lub nie”. Zasada aktualizmu językowego (ang. uniformitarianism), porównującego nakładanie się i przyrastanie warstw języka do nakładania się warstw ziemi, została zapożyczona z geomorfologii do badań zmieniającej się kultury, niemal dwa stulecia temu w Wielkiej Brytanii i Stanach Zjednoczonych (zob. Lubbock 1865), i dość obrazowo, choć niedokładnie pozwala wyobrazić sobie zmiany zachodzące w języku: „(...) struktura języka przypomina strukturę wykopaliska archeologicznego, w którym na najdawniejsze i najpierwotniejsze złoża i warstwy były nakładane coraz to nowe złoża, różniące się mniej lub więcej od poprzednich, po najnowsze - aktualnie, w naszej obecności się tworzące i odkładające" (Anusiewicz 1994: 58). Niemniej istotnym jest, że Anusiewicz natychmiast łagodzi użytą przez siebie metaforę wykopaliska, zauważając, że jest ona niezbyt trafna ${ }^{7}$.

Mając na względzie badania zmieniającego się języka i kultury bardzo trafnym jest uwaga Williama Foleya (1997: 5) uważającego, że językoznawstwo antropologiczne można zdefiniować jako poszukiwanie (zmieniających się) znaczeń w praktykach językowych [podkreślenie - P.C.], mieszczących się z oczywistych względów w obszerniejszych od nich praktykach kulturowych. Stąd według tego autora sam koncept znaczenia powinien być traktowany jako podstawowy w tym polu badawczym. Anusiewicz (1994: 58-59) dodaje jeszcze: „[o]czywiste jest także, że wiele elementów systemu języka, wiele jego kategorii, staje się w toku ewolucji tegoż systemu martwymi i już nieobowiązującymi składnikami dawnego systemu językowego, wychodzącymi całkowicie z użycia, czy przechodząc do kategorii archaizmów językowych - niemniej należy stwierdzić, że zasadniczy zrąb języka, jego jądro, centrum, podstawa i to zarówno w aspekcie semantycznym, jak i leksykalnym i częściowo gramatycznym - pozostaje bez zmian".

Powyższe stwierdzenie wcale nie jest takie oczywiste, bowiem współczesnemu Polakowi byłoby niezmiernie trudno komunikować się w języku staropolskim, podobnie jak i współczesnemu angliście byłoby niezmiernie trudno odnaleźć się i żyć w kulturze języka staro- czy średnioangielskiego. Dlatego też tak ważnym jest uwaga Foleya o 
znaczeniu. W tym też duchu zachowana jest część prac Alessandro Durantiego (1988: 13-33), który spędziwszy dłuższy czas na terenowych badaniach praktyk językowych na Zachodnim Samoa, wskazuje na to, że podczas tamtejszej debaty politycznej wypowiedź nie musi znaczyć tego, co wypowiadający miał na myśli, ale znaczy to, co mówiący mający najmocniejszy status w tej debacie ustalą żeby znaczyła. Tak oto w niewerbalnym kontekście samoańskiej debaty politycznej budowanie znaczenia wypowiedzi staje się skonwencjonalizowanym procesem interpretacji i negocjacji właśnie znaczenia.

Dlatego koncept znaczenia i całego procesu jego budowy w kulturze leży u podwalin każdej praktyki dyskursywnej i perspektyw badawczych językoznawstwa antropologicznego. Innymi słowy, znaczenie zawsze zależy od niewerbalnego kontekstu i werbalnego tekstu, jak i od wiedzy odbiorcy. Dla przykładu, inskrypcje Majów można odbierać zarówno jako przepiękne rzeźby, bardzo skomplikowane inskrypcje lub jako proste i bardzo dokładne określenie jakiegoś dnia w 52-letnim cyklu kalendarza Majów - przy każdym z trzech powyższych sposobów odbioru tych inskrypcji będziemy mieli do czynienia $\mathrm{z}$ innym sposobem budowania znaczenia przez odbiorcę, a dzieje się tak $\mathrm{z}$ uwagi na różnice kulturowe i różne przygotowanie tych odbiorców do czytania tego typu tekstów.

Mając na uwadze powyższe rozważania naturalnie rodzi się postulat rozpropagowania specjalizacji językoznawstwa antropologicznego i upowszechnienie kursu z tego przedmiotu tak, aby mógł on znaleźć się w programie studiów każdego instytutu filologicznego. Stąd też jednym z podstawowych założeń współczesnego językoznawstwa antropologicznego w Polsce powinno być praktyczne przygotowanie studentów do czynnego uczestnictwa w kulturze dynamicznie zmieniających się społeczności mownych, z którymi żyjemy we wspólnej Europie, i uświadomienie, jakim potężnym narzędziem kreowania rzeczywistości wszyscy dysponujemy.

\section{Przypisy}

\footnotetext{
${ }^{1}$ Zakres badania antropologii lingwistycznej byłby identyczny jak lingwistyki antropologicznej, stąd częsta konfuzja w użyciu tych terminów, niemniej można założyć, że używanie ich jako synonimów nie stanowi wielkiego błędu, gdyż w antropologii lingwistycznej nacisk położony jest bardziej na kulturę i wypracowanie opisu praktyk kulturowych dziejących się za pomocą języka, niż zbieranie danych czysto lingwistycznych dotyczących tego jakim językiem, rejestrem, itp. posługuje się badana osoba w danym zanurzeniu sytuacyjnym.

${ }^{2}$ Zob. Janusz Anusiewicz (1994:10). Główny obszar zainteresowań i zakres lingwistyki kulturowej obejmuje przede wszystkim historię zagadnienia badawczego relacji: język - kultura; stan badań nad tym zagadnieniem; teoretyczne i metodologiczne aspekty tego zagadnienia; kulturowe i kulturotwórcze (niekiedy też państwowotwórcze, np. w Izraelu) funkcje języka w różnych formach i sposobach jego istnienia;
} 
dziedzictwo kulturowe utrwalone w repertuarze danego języka narodowego lub mniejszościowego; zob. też Anusiewicz (1994: 15-16).

${ }^{3}$ Gdzie język jest traktowany jako „(...) zjawisko społeczno-poznawczo-kulturowo-komunikacyjne, a nie tylko jako środek i narzędzie porozumiewania (...)”, co więcej w takim rozumieniu język jest „,...) psychofizycznym nośnikiem myśli o charakterze społeczno-kulturowym. Stanowi rezultat procesów i sposobów poznania taki, że myśli spełniają się w języku. Zawiera określoną klasyfikację i hierarchizację oraz taksonomizację (uporządkowanie) świata, co przejawia się w kategoryzacji semantycznej, otwierającej jako genus proximum definicje semantyczne. Jest zarazem interpretacją i aksjologizacją rzeczywistości. W tym ujęciu tekst stanowi językowy mikromodel określonego wycinka rzeczywistości, zorganizowany według wymienionych zasad" Anusiewicz (1994: 113).

${ }^{4}$ Dokładniejsza dyskusja na ten temat jest opublikowana w pracy Piotra P. Chruszczewskiego pt. Jezykoznawstwo antropologiczne. Zadania i metody. Wrocław 2011.

5 "If cultural practices are those meaningful practices through which humans in relationships sustain ongoing histories of social structure coupling, then foremost among these must be linguistic practices. What people do incessantly in every known society is talk. Linguistic practices are the most pervasive way in which humans make meanings and sustain social systems; they do not exhaust human cultural practices, but are clearly primary among them. Humans could be succinctly defined as social beings encultured through language" William Foley (1997: 24).

6 "[A linguistic practice] (...) is any communicative practice which promotes coordination of action between beings in ongoing social structural coupling through the meaning bearing capacity of signs drawn from a large system of signs and their combinatorial possibilities called language" William Foley (1997: 24).

${ }^{7}$ „Różnica między wykopaliskiem a językiem (jego częściami składowymi i strukturą) być może jest głównie taka, że w przypadku języka owe warstwy pierwotne - ujęcie fundamentalne i podstawowe, części składowe powstałe w zamierzchłych, bardzo odległych czasach, funkcjonują do dziś, będąc żywotnymi, używanymi, obowiązującymi i aktualnie ważnymi częściami systemu językowego, czy też jego konkretnych realizacji tekstów, podczas gdy wykopalisko jest martwe, informuje o przeszłości” Janusz Anusiewicz (1994: 58).

\section{Źródło}

Tekst ten został po raz pierwszy opublikowany w pracy pt. Studia językoznawcze: od językoznawstwa teoretycznego do stosowanego. Seria: Języka a komunikacja. Jacek Fisiak (red.) Kraków: TERTIUM (2010: 57-68).

\section{Bibliografia}

Anusiewicz, Janusz (1994) Lingwistyka kulturowa. Zarys problematyki. Wrocław: Wydawnictwo Uniwersytetu Wrocławskiego.

Blount, Ben G. (1995) “Anthropological Linguistics". [W:] Jef Verschueren, Jan-Ola Östman, Jan Blommaert (red.). Handbook of Pragmatics: Manual. Amsterdam, Philadelphia: John Benjamins; 36-45. 
Bowern, Claire (2008) Linguistic Fieldwork. A Practical Guide. Houndmills, New York: Palgrave Macmillan.

Carruthers, Peter (1996) Language, Thought and Consciousness. An Essay in Philosophical Psychology. Cambridge: Cambridge University Press.

Chruszczewski, Piotr P. (2011) Językoznawstwo antropologiczne. Zadania i metody. Wrocław: Oddział Polskiej Akademii Nauk we Wrocławiu.

Duranti, Alessandro (1988) "Intentions, Language, and Social Action in a Samoan Context". [W:] Journal of Pragmatics 12; 13-33.

Fodor, Jerry A. (1975) The Language of Thought. New York: Crowell.

Fodor, Jerry A. (1983) The Modularity of the Mind. Cambridge, MA: MIT Press.

Foley, William A. (1997) Antropological Linguistics. An Introduction. Malden, MA; Oxford U.K.: Blackwell Publishing.

Gumperz, John J., Stephen C. Levinson (1996) "Introduction: Linguistic Relativity Reexamined". [W:] John J. Gumperz and Stephen C. Levinson (red.) Rethinking Linguistic Relativity. Cambridge: Cambridge University Press; 1-18.

Klein, H.E. Manelis (2006) “Anthropological Linguistics: Overview”. [W:] Encyclopedia of Language \& Linguistics. $2^{\text {nd }}$ ed. Keith Brown (red. naczelny). Amsterdam, Boston: Elsevier; 296-304.

Levinson, Stephen C. ([1997] 2003) “Linguistic Relativity". [W:] International Encyclopedia of Linguistics. William J. Frawley (red. naczelny). Oxford: Oxford University Press; 459-463.

Levinson, Stephen C. (1997) "From Outer to Inner Space: Linguistic Categories and Neolinguistic Thinking". [W:] With Language in Mind: The Relationship Between Linguistic and Conceptual Representation. E. Pederson, J. Nuyts (red.). Cambridge: Cambridge University Press; 13-45.

Lubbock, John (1865) Pre-historic Times, as Illustrated by Ancient Remains, and the Manners and Customs of Modern Savages. London: Williams and Norgate.

Lucy, John A. (1992) Language Diversity and Thought. A Reformulation of the Linguistic Relativity Hypothesis. Cambridge: Cambridge University Press.

Pinker, Steven (1994) The Language Instinct. London, New York: Penguin Books.

Powell, John W. ([1877] 1880) Introduction to the Study of Indian Languages. With Words, Phrases, and Sentences to be Collected. Washington, D.C.: BAE, Smithsonian Institution. 
Whorf, Benjamin Lee (1956) Language, Thought, and Reality: Selected Writings of Benjamin Lee Whorf. John B. Caroll (red.) Cambridge, MA: The Massachusetts Institute of Technology Press. (Oryginalne prace powstałe w latach 1927-1941). Wierzbicka, Anna (1996) Semantic Primes and Universals. Oxford: Oxford University Press. 